\title{
Analysis of the German Perinatal Survey of the Years 2007-2011 and Comparison with Data From 1995-1997: Maternal Characteristics
}

\author{
Analyse der Deutschen Perinatalerhebung der Jahre 2007-2011 \\ und Vergleich mit den Daten von 1995-1997: maternale Charakteristika
}

Authors

Affiliations
R. Scholz ${ }^{1}$, M. Voigt ${ }^{2}$, K. T. M. Schneider ${ }^{3}$, N. Rochow ${ }^{4}$, H.-P. Hagenah ${ }^{5}$, V. Hesse ${ }^{2}$, S. Straube ${ }^{6}$

The affiliations are listed at the end of the article.

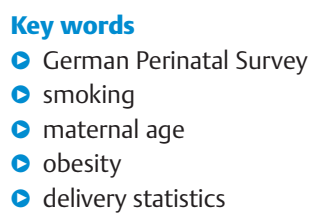

Schlüsselwörter

- Deutsche Perinatalerhebung

- Rauchen

- mütterliches Alter

- Adipositas

- Geburtenstatistik $\begin{array}{lr}\text { received } & 14.5 .2013 \\ \text { revised } & 17.6 .2013 \\ \text { accepted } & 20.8 .2013\end{array}$

Bibliography

Dol http://dx.doi.org/

10.1055/s-0033-1350830

Geburtsh Frauenheilk 2013; 73 :

1247-1251 @ Georg Thieme

Verlag KG Stuttgart · New York . ISSN 0016-5751

\section{Correspondence}

PD Dr. Dr. Manfred Voigt

German Center for Growth,

Development and Health

Encouragement during Child-

hood and Youth, Berlin

Working Group Rostock-

Sievershagen

Kükensteg 13

18069 Sievershagen

voim13@t-online.de

\section{Abstract}

$\nabla$

Background and Aim: We have previously presented analyses of data obtained from the German Perinatal Survey for the years 1995-1997. Here we present an analysis of data from the years 2007-2011 and compare the data to the previous data from the 1990s.

Material and Methods: For the years 1995-1997, the data on 1815318 singleton pregnancies were provided by the Chambers of Physicians of all the states of Germany except Baden-Württemberg. For the years 2007-2011, the data on 3187920 singleton pregnancies from the German Perinatal Survey (all states of Germany) were obtained from the AQUA Institute in Göttingen, Germany. SPSS was used for data analysis. Plausibility checks were performed on the data.

Results: Mean maternal age has increased over the years, from 28.7 years in 1995 to 30.2 years in 2011. We observed a decrease in smoking. While not all cases included data on maternal smoking after the pregnancy was known, when the cases with data on smoking were analysed, in $1995-199723.5 \%$ of pregnant women were smokers compared to $11.2 \%$ smokers in 2007 2011. Maternal body mass index (BMI) also changed; $8.2 \%$ of women were obese (BMI: 30 $40 \mathrm{~kg} / \mathrm{m}^{2}$ ), while $13.0 \%$ were obese in 2011 . In $1995,0.6 \%$ of women were morbidly obese (BMI $\geq 40 \mathrm{~kg} / \mathrm{m}^{2}$ ) compared to $1.8 \%$ of women in 2011 . The mean maternal body weight at the time of the first obstetric consultation also increased from $65.9 \mathrm{~kg}$ in 1995 to $68.7 \mathrm{~kg}$ in 2011.

Conclusions: While the decrease in the number of women smoking over time is clearly a positive development, increasing maternal age and obesity present challenges in clinical practice.

\section{Zusammenfassung \\ $\nabla$}

Hintergrund und Fragestellung: Analysen der Deutschen Perinatalerhebung der Jahre 19951997 sind in der Vergangenheit von uns vorgestellt worden. Hier werden die Daten der Jahre 2007-2011 analysiert und mit den vorherigen Daten aus den 1990er-Jahren verglichen.

Material und Methodik: Für die Jahre 1995 bis 1997 wurden Daten von 1815318 Einlingsschwangerschaften von den Ärztekammern aller Bundesländer außer Baden-Württemberg zur Verfügung gestellt. Für die Jahre 2007 bis 2011 wurden Daten von 3187920 Einlingsschwangerschaften der Deutschen Perinatalerhebung (alle Bundesländer) vom AQUA-Institut in Göttingen bereitgestellt. Die Datenanalyse wurde mit SPSS durchgeführt. Plausibilitätsprüfungen wurden an den Daten vorgenommen.

Ergebnisse: Das durchschnittliche mütterliche Alter stieg von 28,7 (1995) auf 30,2 Jahre (2011). Ein Rückgang des Rauchens konnte beobachtet werden. Mit der Einschränkung, dass nicht für alle Fälle Daten zum Rauchen nach Bekanntwerden der Schwangerschaft vorhanden waren, ergab eine Analyse der Fälle mit solchen Daten einen Anteil von 23,5\% Raucherinnen (1995-1997) vs. 11,2\% (2007-2011). Der mütterliche BodyMass-Index (BMI) veränderte sich ebenfalls; der Anteil adipöser Frauen mit einem BMI von 30$40 \mathrm{~kg} / \mathrm{m}^{2}$ betrug 1995 8,2\% und 2011 13,0\%. 1995 hatten $0,6 \%$ einen $\mathrm{BMI} \geq 40 \mathrm{~kg} / \mathrm{m}^{2}$; bis 2011 verdreifachte sich dieser Anteil auf 1,8\%. Das mittlere Körpergewicht der Schwangeren zum Zeitpunkt der Erstuntersuchung stieg von 65,9 kg im Jahr 1995 auf 68,7 kg im Jahr 2011.

Schlussfolgerungen: Während der Rückgang des Rauchens als positive Entwicklung zu sehen ist, stellen steigendes mütterliches Alter und Adipositas Herausforderungen für die klinische Praxis dar. 


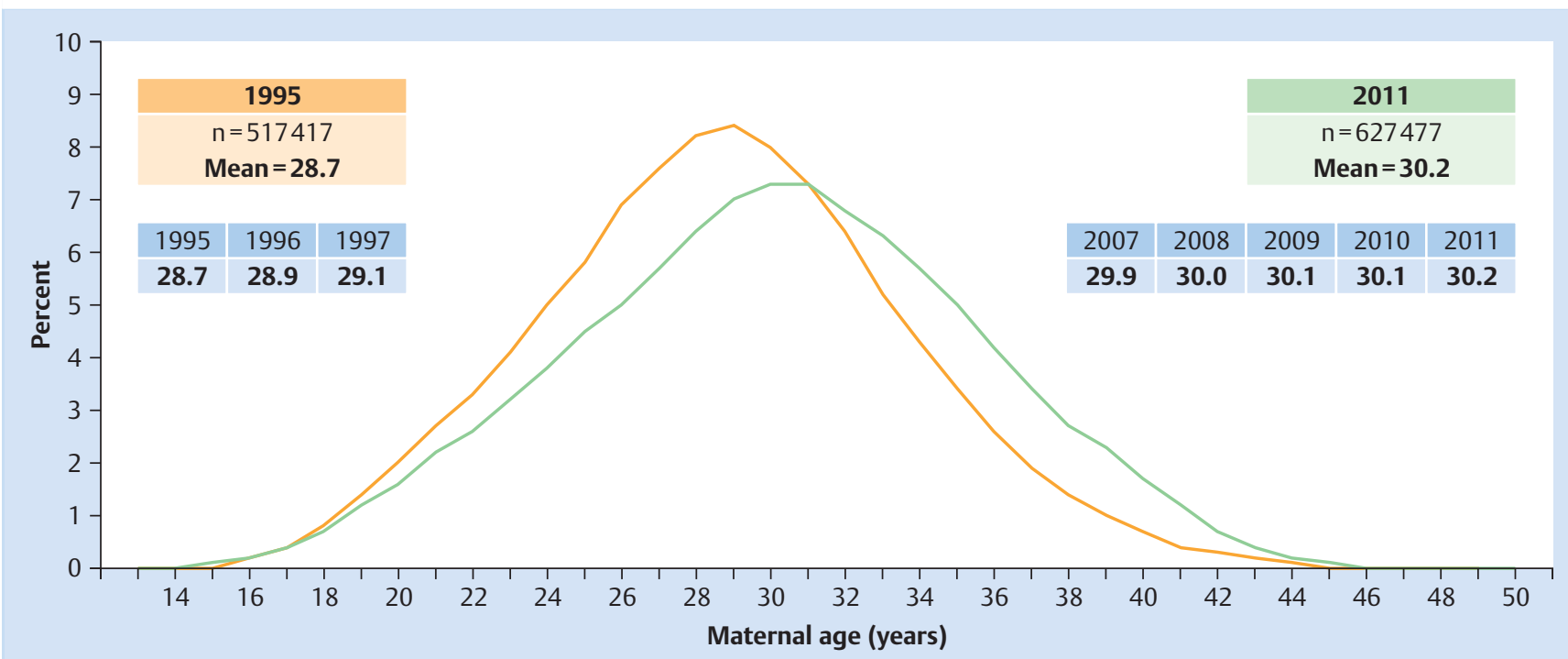

Fig. 1 Maternal age (calculated as the year of the infant's birth minus the year of the mother's birth). The distributions for maternal age and the contributing case numbers (n) for the years 1995 and 2011 are shown as well as the mean maternal ages for each year from 1995 to 1997 and from 2007 to 2011.

\section{Introduction}

The German Perinatal Survey is routinely conducted in all of Germany. It offers the opportunity to analyse temporal trends in maternal and neonatal characteristics by comparing data from different years. We have previously presented analyses of data from the Perinatal Survey for the years 1995-1997 [1,2]. We have now analysed data from the years 2007-2011. In this paper we present our analysis of the maternal characteristics "age", "body mass index" (BMI), and "smoking", and compare these data with the previous data from the 1990s. Neonatal characteristics and duration of pregnancy will be examined in a separate publication.

\section{Material and Methods}

$\nabla$

The data analysed in the present report were obtained from the routine data collection undertaken by the German Perinatal Survey, a mandatory survey that is conducted throughout Germany. For the years 1995-1997, one of us, Manfred Voigt, was kindly provided with data on 1815318 singleton pregnancies by the Chambers of Physicians of all the states of Germany except Baden-Württemberg. These data were collected into a database and analysed. For the years 2007-2011, data from the German
Perinatal Survey were provided to another one of our group, Rembrandt Scholz, by the AQUA Institute (AQUA-Institut für angewandte Qualitätsförderung und Forschung im Gesundheitswesen) in Göttingen, Germany; data on 3187920 singleton pregnancies from all the states of Germany including Baden-Württemberg were analysed. Statistical analysis was done using the SPSS computer programme. To minimise the effects of data entry errors, plausibility checks were performed on the data; implausible values were excluded from the analysis.

\section{Results}

$\nabla$

Between 2007 and 2011, a total of 3302061 births were recorded in the German Perinatal Survey. The majority (3187920) of these were singleton births; these singleton pregnancies are investigated in the present report. Multiple births accounted for less than $4 \%$ of total births in each year ( Table 1 ).

Mean maternal age (calculated as the year of the infant's birth minus the year of the mother's birth) has increased over the years, from 28.7 years in 1995 to 30.2 years in 2011. The distributions of maternal age in 1995 and in 2011 show that in 2011, there were more older mothers and fewer younger mothers compared to 1995 (๑ Fig. 1).

Table 1 Singleton and multiple births in Germany 2007-2011.

\begin{tabular}{|c|c|c|c|c|c|c|c|c|c|c|c|}
\hline & 2007 & & 2008 & & 2009 & & 2010 & & 2011 & & Total \\
\hline & $\mathbf{n}$ & $\%$ & $\mathbf{n}$ & $\%$ & $\mathbf{n}$ & $\%$ & $\mathbf{n}$ & $\%$ & $\mathbf{n}$ & $\%$ & $\mathbf{n}$ \\
\hline Singletons & 647394 & 96.7 & 647136 & 96.7 & 627542 & 96.5 & 638337 & 96.4 & 627511 & 96.5 & 3187920 \\
\hline Twins & 21258 & 3.2 & 21562 & 3.2 & 21944 & 3.4 & 23192 & 3.5 & 22357 & 3.4 & 110313 \\
\hline Triplets & 692 & 0.1 & 768 & 0.1 & 728 & 0.1 & 795 & 0.1 & 707 & 0.1 & 3690 \\
\hline Quadruplets & 20 & & 22 & & 33 & & 28 & & 22 & & 125 \\
\hline Quintuplets & 0 & & 0 & & 0 & & 5 & & 0 & & 5 \\
\hline Sextuplets & 2 & & 6 & & 0 & & 0 & & 0 & & 8 \\
\hline Total & 669366 & 100.0 & 669494 & 100.0 & 650247 & 100.0 & 662357 & 100.0 & 650597 & 100.0 & 3302061 \\
\hline
\end{tabular}




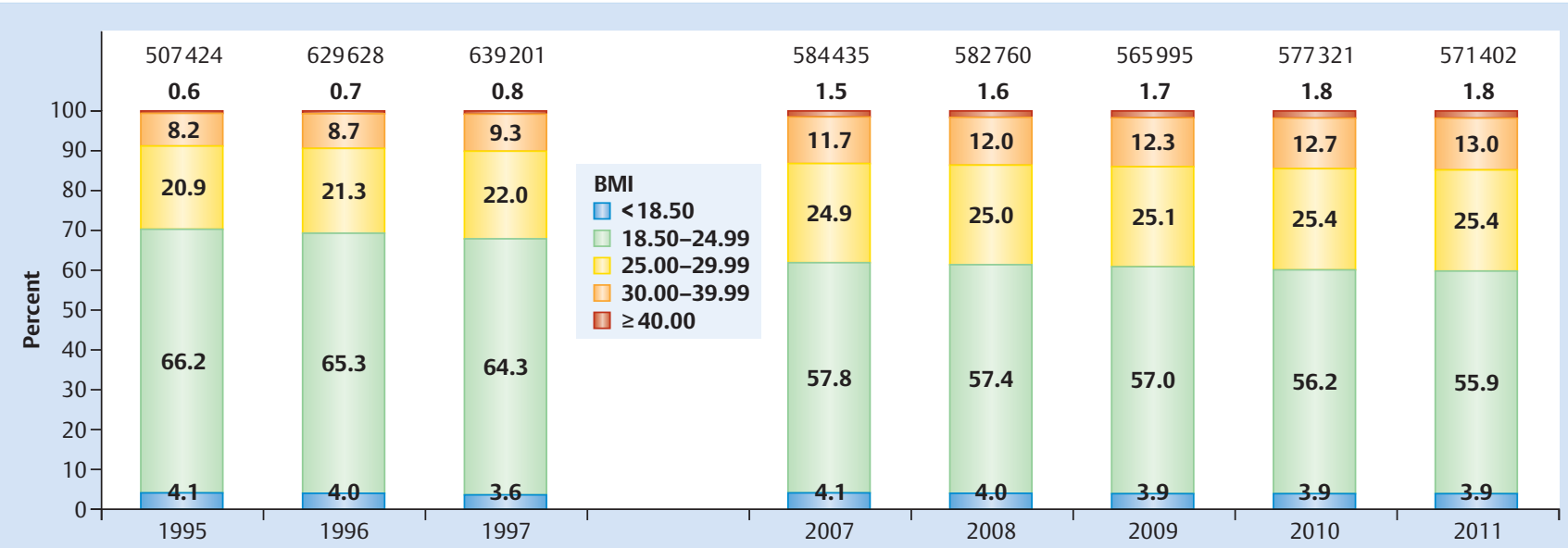

Fig. 2 Maternal body mass index (BMI, in $\mathrm{kg} / \mathrm{m}^{2}$ ) at the first obstetric consultation. The percentages of women within the BMI ranges are shown for each year; case numbers are displayed at the top of the columns.

We observed a decrease in the number of women smoking. The German Perinatal Survey collects data on maternal smoking after the pregnancy is known; however, in many cases this information is missing (49.0\% of all cases in the 1995-1997 dataset had no data on maternal smoking, and $20.2 \%$ of all cases in the 2007-2011 dataset lacked this information). When only the cases with data on smoking were analysed, $23.5 \%$ of women were smokers in the $1995-1997$ period compared to $11.2 \%$ of women in the period from 2007-2011.

Maternal BMI at the first obstetric consultation has also changed over time ( $\bullet$ Fig. 2 ). While the percentage of underweight women has remained roughly constant at around $4 \%$, there has been a notable increase in overweight, obese and morbidly obese women, and a corresponding drop in the percentage of women with normal weight. Obese women with a BMI between 30 and
$40 \mathrm{~kg} / \mathrm{m}^{2}$ accounted for $8.2 \%$ of all pregnant women investigated in 1995 and $13.0 \%$ in 2011. In 1995, 0.6\% of women were morbidly obese (BMI $\geq 40 \mathrm{~kg} / \mathrm{m}^{2}$ ); in $2011,1.8 \%$ of women were in this BMI category, a three-fold increase. Mean maternal body weight (at the time of the first obstetric consultation) has also increased over time from $65.9 \mathrm{~kg}$ in 1995, $66.3 \mathrm{~kg}$ in 1996 and $66.8 \mathrm{~kg}$ in 1997 to $67.8 \mathrm{~kg}$ in 2007, $68.1 \mathrm{~kg}$ in $2008,68.3 \mathrm{~kg}$ in 2009, $68.6 \mathrm{~kg}$ in 2010 and $68.7 \mathrm{~kg}$ in 2011.

- Table 2 shows the maternal characteristics for the different states of Germany for the years 2007-2011. Because the state of North Rhine-Westphalia has two Chambers of Physicians collecting perinatal data, "Westfalen-Lippe" and "Nordrhein", there are two entries for North Rhine-Westphalia in the table. Mean maternal age ranged from 28.3 years (Saxony-Anhalt) to 31.3 years (Hamburg). The percentage of obese pregnant women was lowest

Table 2 Maternal characteristics in the different states of Germany 2007-2011 (singleton pregnancies). There are 17 entries for the 16 states of Germany because one state, North Rhine-Westphalia, has two Chambers of Physicians collecting perinatal data, "Westfalen-Lippe" and "Nordrhein". Weight, height, and body mass index (BMI) are from the time of the first obstetric consultation. The states of Germany/Chambers of Physicians are presented in order of mean maternal height; $\mathrm{n}$ - contributing case numbers.

\begin{tabular}{|c|c|c|c|c|c|}
\hline State of Germany & Age (years) & Weight (kg) & Height $(\mathrm{cm})$ & $\mathrm{BMI} \geq 30$ (\%) & n \\
\hline Schleswig-Holstein & 29.9 & 70.8 & 167.8 & 16.8 & 96193 \\
\hline Mecklenburg-Western Pomerania & 28.4 & 68.9 & 167.5 & 14.4 & 60728 \\
\hline Lower Saxony & 29.9 & 70.3 & 167.5 & 16.5 & 288627 \\
\hline Hamburg & 31.3 & 67.2 & 167.4 & 11.2 & 96046 \\
\hline Brandenburg & 28.7 & 67.9 & 166.9 & 13.7 & 72042 \\
\hline Bremen & 30.0 & 69.5 & 166.9 & 15.9 & 37967 \\
\hline North Rhine-Westphalia (1) & 29.7 & 69.8 & 166.9 & 16.3 & 317510 \\
\hline \multicolumn{6}{|c|}{ Chamber of Physicians Westfalen-Lippe } \\
\hline Saxony & 29.0 & 66.9 & 166.8 & 11.5 & 165655 \\
\hline Berlin & 30.1 & 66.0 & 166.7 & 10.4 & 163756 \\
\hline Bavaria & 30.5 & 67.2 & 166.7 & 12.2 & 497418 \\
\hline Thuringia & 28.6 & 67.7 & 166.7 & 13.4 & 74461 \\
\hline North Rhine-Westphalia (2) & 30.3 & 68.8 & 166.6 & 15.1 & 380059 \\
\hline \multicolumn{6}{|l|}{ Chamber of Physicians Nordrhein } \\
\hline Saxony-Anhalt & 28.3 & 68.2 & 166.6 & 14.8 & 81157 \\
\hline Hesse & 30.5 & 68.1 & 166.5 & 13.9 & 236892 \\
\hline Rhineland-Palatinate & 29.8 & 69.0 & 166.4 & 16.1 & 150196 \\
\hline Baden-Württemberg & 30.6 & 67.4 & 166.3 & 13.0 & 433144 \\
\hline Saarland & 29.6 & 68.7 & 165.7 & 17.0 & 36069 \\
\hline Total & 30.0 & 68.3 & 166.8 & 14.0 & 3187920 \\
\hline
\end{tabular}


in Berlin (10.4\%) and highest in the Saarland (17.0\%). Mean maternal height was greater in the northern states of Germany (more than $167 \mathrm{~cm}$ in Schleswig-Holstein, Mecklenburg-Western Pomerania, Lower Saxony, and Hamburg) compared to the states further south.

\section{Discussion \\ $\nabla$}

The comparison of data collected by the German Perinatal Survey for the years 1995-1997 and 2007-2011 allows temporal trends in maternal characteristics to be identified. Important trends include increasing mean maternal age, a decreasing percentage of smoking women, and an increasing percentage of overweight, obese, and, especially, morbidly obese women. We describe a decrease in the numbers of smoking women over time, although this finding has to be interpreted with caution due to the high percentage of cases which lacked any data on maternal smoking. It should be noted, however, that a similar trend of decreasing numbers of women smoking, albeit somewhat less pronounced, has also been described elsewhere. Göhlmann and Schmidt [3] reported a decrease in smoking rates among women in two relevant age groups, 25-29 years and 30-34 years, when comparing micro census data from the German Federal Statistical Office for the years 1995, 1999 and 2003, although smoking rates were still in excess of $30 \%$. The 2005 and 2009 micro censuses showed a further decline in the rate of smokers for women aged 30-34 years to 29 and $28 \%$, respectively [4,5]. The differences in the rates of smoking women between the German Perinatal Survey data and the German Federal Statistical Office micro census data may have been because in the former survey pregnant women were asked about their smoking after their pregnancies became known; rates of smokers can be expected to be lower compared to the overall rate for all women (whether pregnant or not). While the decrease in smoking women over time is clearly a positive development, increasing maternal age and obesity rates present challenges in clinical practice. Smoking has been linked to a number of adverse perinatal outcomes, some of which have been reported in analyses of the German Perinatal Survey [6-10], although hypertensive disorders of pregnancy seem to occur less commonly in smokers [11]. The risks associated with maternal obesity have also been described $[8,9,12,13]$. Finally, it has been shown that late motherhood is associated with perinatal risks $[14,15]$.

A comparison of the states of Germany revealed inter alia that maternal height tended to be higher in the northern States of Germany. This difference was also noted in our previous analysis of data from the German Perinatal Survey [2].

Some limitations of our approach need to be discussed. Errors in data entry are always a concern and indeed, some values in the datasets of the German Perinatal Survey were implausible. We aimed to deal with data entry errors by excluding implausible values from our analysis but we have no way of detecting data entry errors that are not obviously implausible. However, it seems unlikely that this should introduce a systematic bias. Another limitation concerns differences in how data were handled in the two time periods and the completeness of the data. For 19951997, one of our group, Manfred Voigt, was provided with the data of the German Perinatal Survey by the Chambers of Physicians of all the states of Germany except Baden-Württemberg. For the years 2007-2011, another of our group, Rembrandt Scholz, was given access to the data for all the states of Germany including
Baden-Württemberg by the AQUA Institute. Not having the data for one of the states of Germany for the period of time 19951997 as well as the different ways in which data were analysed are potential sources of error. Comparisons between the two periods of time need to be interpreted with these limitations in mind. Finally, as with all survey data reported by participants which has not been objectively verified, there is the potential for deliberate misinformation on the part of the participants themselves, especially with regard to answers to questions on unhealthy lifestyles, such as smoking during pregnancy. This may also have contributed in the large percentage of missing data for this question. As mentioned above, our data on smoking during pregnancy should therefore be interpreted with caution.

\section{Acknowledgements \\ $\nabla$}

We would like to thank the Chambers of Physicians of the states of Germany for contributing perinatal data for the years 19951997 and we thank the AQUA Institute for allowing us access to their data. We are grateful to Christel Fernow for help in preparing the figures and tables.

\section{Conflict of Interest \\ $\nabla$}

The authors have no conflicts of interest to disclose.

\author{
Affiliations \\ ${ }^{1}$ Max Planck Institute for Demographic Research, Rostock, Germany \\ ${ }^{2}$ German Center for Growth, Development and Health Encouragement \\ during Childhood and Youth, Berlin, Germany \\ ${ }^{3}$ Section of Perinatal Medicine, Department of Obstetrics, Technical University \\ of Munich, Germany \\ ${ }^{4}$ Division of Neonatology, Department of Pediatrics, McMaster University, \\ Hamilton, Canada \\ ${ }^{5}$ Diakoniekrankenhaus Rotenburg (Wümme) gGmbH, Rotenburg (Wümme), \\ Germany \\ ${ }^{6}$ Institute of Occupational, Social and Environmental Medicine, University \\ Medical Center Göttingen, Germany
}

\section{References}

1 Voigt M, Friese K, Pawlowski P et al. Analyse des Neugeborenenkollektivs der Jahre 1995-1997 der Bundesrepublik Deutschland. 6. Mitteilung: Unterschiede in der Geburtsgewichtsklassifikation in den einzelnen Bundesländern unter Zugrundelegung einer einheitlichen Normwertkurve für Deutschland (unter Berücksichtigung anthropometrischer Merkmale der Mütter). Geburtsh Frauenheilk 2001; 61: 700-706

2 Voigt M, Schneider KTM, Stillger R et al. Analyse des Neugeborenenkollektivs der Bundesrepublik Deutschland. 9. Mitteilung: Durchschnittliche Geburtsgewichte, Raten Neugeborener mit niedrigem und hohem Geburtsgewicht und Frühgeborenenraten unter Berücksichtigung der einzelnen Bundesländer in Deutschland. Geburtsh Frauenheilk 2005; 65: 474-481

3 Göhlmann S, Schmidt CM. Smoking in Germany: stylized facts, behavioral models, and health policy. Ruhr Economic Papers \#64. 2008. Online: http://en.rwi-essen.de/publikationen/ruhr-economic-papers/ 21/; last access 17.04.2013

4 Federal Statistical Office (Germany). Mikrozensus - Fragen zur Gesundheit - Rauchgewohnheiten der Bevölkerung 2005. 2006. Online: https://www.destatis.de/DE/Publikationen/Thematisch/Gesundheit/ Gesundheitszustand/Rauchgewohnheiten5239004059004.pdf? blob=publicationFile; last access: 18.04.2013

5 Federal Statistical Office (Germany). Mikrozensus - Fragen zur Gesundheit - Rauchgewohnheiten der Bevölkerung 2009. 2011. Online: https://www.destatis.de/DE/Publikationen/Thematisch/Gesundheit/ Gesundheitszustand/Rauchgewohnheiten5239004099004.pdf; jsessionid=5E292DA5F85ABCDA82517F7E3FF3E6C3.cae1?_blob= publicationFile; last access: 18.04.2013 
6 Voigt M, Straube S, Fusch $C$ et al. Erhöhung der Frühgeborenenrate durch Rauchen in der Schwangerschaft und daraus resultierende Kosten für die Perinatalmedizin in Deutschland. Z Geburtshilfe Neonatol 2007; 211: 204-210

7 Voigt $M$, Briese $V$, Jorch $G$ et al. The influence of smoking during pregnancy on fetal growth - considering daily cigarette consumption and the SGA rate according to length of gestation. Z Geburtshilfe Neonatol 2009; 213: 194-200

8 Voigt $M$, Jorch G, Briese $V$ et al. The combined effect of maternal body mass index and smoking status on perinatal outcomes - an analysis of the German perinatal survey. Z Geburtshilfe Neonatol 2011; 215: 23 28

9 Voigt M, Zels K, Guthmann F et al. Somatic classification of neonates based on birth weight, length, and head circumference: quantification of the effects of maternal BMI and smoking. J Perinat Med 2011; 39: 291-297
10 Krentz H, Voigt M, Hesse Vet al. Influence of smoking during pregnancy specified as cigarettes per day on neonatal anthropometric measurements - an analysis of the German perinatal survey. Geburtsh Frauenheilk 2011; 71: 663-668

11 Voigt M, Neudecker K, Schneider KT et al. Effects of smoking specified as cigarettes per day and maternal body mass index on hypertensive disorders of pregnancy. Z Geburtsh Neonatol 2013; 217: 24-27

12 Voigt $M$, Straube S, Zygmunt $M$ et al. Obesity and pregnancy - a risk profile. Z Geburtshilfe Neonatol 2008; 212: 201-205

13 Briese V, Voigt $M$, Wisser J et al. Risks of pregnancy and birth in obese primiparous women: an analysis of German perinatal statistics. Arch Gynecol Obstet 2011; 283: 249-253

14 Voigt M, Rochow N, Zygmunt $M$ et al. Risks of pregnancy and birth, birth presentation, and mode of delivery in relation to the age of primiparous women. Z Geburtshilfe Neonatol 2008; 212: 206-210

15 Schure V, Voigt M, Schild RL et al. Perinatal risks in 'late motherhood' defined based on parity and preterm birth rate - an analysis of the German Perinatal Survey (20th communication). Geburtsh Frauenheilk 2012; 72: 49-55 